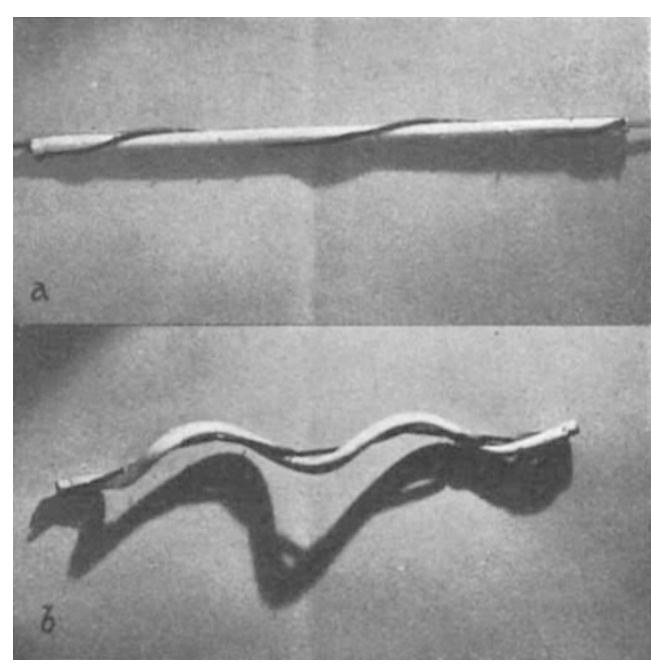

Fig. 3. Models of spirochætes : (a) a black elastic band flxed spirally and under tension around a white rubber tube, which is held rigid by a metal rod threaded through it ; $(b)$ the same after the metal rod has been removed, so that the elastic band is allowed to contract. In both $(a)$ and $(b)$ the model is lighted from in an irregular spiral in $(b)$

fibrils during tryptic digestion. Instead of dissolving homogeneously, the fibrils break down into strings of beads. What is of particular interest is that the distance between adjacent beads, although fairly constant along any one fibril, varies considerably from one fibril to another. This is so like what is found in the fine structure of striated muscle fibres - where the inter-bead distance appears to vary with the state of contraction of the muscle-as to suggest that the bundle of fibrils of the spirochæte is similarly contractile, and hence that it acts like the elastic band in our models to confer on the spirochæte its spiral form.

However, it would be unwise to elaborate this aspect without further study. For the present, we wish only to establish the existence of these systems of spirally wound fibrils, which seem to be unique structural devices found in all the spirochætes studied here-but only in them-and which thus serve to define the group as a whole and to distinguish it clearly from all related micro-organisms.

We are indebted to Dr. W. E. Kershaw, of the Liverpool School of Tropical Medicine, Dr. J. S. N. Boyd, of the Wellcome Laboratories of Tropical Medicine, London, and Dr. R. M. Fry, of the Public Health Laboratory, Cambridge, for supplying us with organisms ; to Prof. J. S. Mitchell for the use of his ultra-violet equipment, and to Prof. J. Gray for stimulating our interest in spirochretes. We hope to describe this work more fully elsewhere and to discuss there its relevance to the many previous studies in this field.

Since this article was submitted, we have found that spirally wound fibrils of the kind observed in all the spirochætes mentioned above exist also in the syphilis parasite, Treponema pallidum (the cultured, pathogenic, Nichols strain, kindly supplied by Dr. C. W. Chacko, of the Wright-Fleming Institute).

${ }^{1}$ Dobell, C., Arch. Protistenkunde, 26, 117 (1912).

'Zuelzer, M., in Prowazek's "Handb. d. path. Protozoen", 3, 1628

(1923); see also Noguchi, H., in Jordan and Falk's 'Newer

Knowledge of Bacteriology and Immunology" (1928).

'Gray, J., Nature, 168; 929 (1951).

\section{DEPARTMENT OF SCIENTIFIC AND INDUSTRIAL RESEARCH \\ ANNUAL REPORT}

THE thirty-sixth report of the Department of Scientific and Industrial Research* covers the year ended September 30, 1951. Besides the report of the Committee of the Privy Council over Lord Woolton's signature, and that of the Advisory Council signed by Sir Ian Heilbron, it includes the usual summary of work carried out by the various research stations and boards and research associations. Appendixes, besides the usual lists of assessors to the Advisory Council and of members of the research boards of the Department, of research associations and of grants for special investigations in progress during the year, include once more a classified list of departmental publications issued during the year.

The gross expenditure of the Department for the year ended March 31, 1951, was $£ 5,007,822$, as against $£ 4,346,580$ in the previous year ; but this was reduced by receipts from various sources to $£ 4,554,422$, the net increase on $1949-50$ being $£ 640,640$. The total staff of all grades employed in the Department on October 1, 1951, was 4,088 (including 150 part-time), an increase of 172 over the previous year, compared with increases of 455 and 758 in $1949-50$ and 1948 . 49 , respectively. The increase includes 39 members of the staff of the Technical Information and Documents Unit transferred from the Board of Trade on April 1, 1951. The largest single item of net expenditure was the annual grants to research associations, totalling $£ 1,156,358$, besides special grants of $£ 270,959$. Gross expenditure on the National Physical Laboratory was $£ 726,978$, reduced by receipts to $£ 468,848$ net. Grants for special

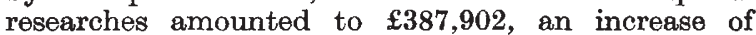
$£ 43,492$, and grants to students to $£ 236,712$ net, an increase of $£ 24,657$. Net expenditure on building research was $£ 491,521$, an increase of $£ 236,188$, but otherwise net expenditures of $£ 243,982$ on road research, of $£ 200,931$ on fuel research, $£ 176,809$ on food investigation, $£ 107,566$ on mechanical engineering, $£ 96,986$ on forest products research, $£ 47,013$ on water pollution, $£ 43,617$ on pest infestation, $£ 25,998$ on hydraulics and $£ 19,977$ on fire research were of the same order as during 1949-50, though that on food investigation was down by $£ 8,597$ and that on mechanical engineering was up by $£ 54,900$. Expenditure on radio research decreased sharply, by $£ 36,079$, to $£ 29,606$ net. Of the gross expenditure of $£ 117,117$ on the Chemical Research Laboratory and of $£ 44,352$ on fire research, $£ 42,934$ and $£ 24,375$, respectively, was covered by receipts. Net expenditure on the Geological Survey and Museum was $£ 158,201$, on headquarters administration $£ 103,483$, on headquarters intelligence $£ 48,756$ and on headquarters overseas liaison $£ 57,266$. Research contracts amounted to $£ 70,606$ net, compared with $£ 139,134$ in $1949-50$.

The number of students-in-training was 910 , compared with 828 in 1949-50, and of these 382 were new. The number of senior research awards, of which three were new, was ten compared with sixteen in 1949-50, and fifty new grants for special investigations, brought the total of such grants to ninety-five compared with ninety-three in 1949-50. The pre-

* Department of Scientific and Industrial Research. Report for the Year 1950-51. (Cmd. 8494.) Pp. 271. (London: H.M. Stationery
Office, 1952.) 78. 6d. net. 
ponderance in chemistry and physics continued : of senior research awards, three were in chemistry, six in physics and one in biology; and of the grants for special investigations, 27 were in chemistry, 41 in physics and 13 in engineering. Of the grants to students, 366 were in chemistry, 283 in physics, 68 in biology, 66 in engineering, 58 in mathematics and astronomy, 36 in geology and mineralogy and 33 in metallurgy.

The most important feature of this year's report of the Advisory Council is the note of anxiety which it displays concerning the future of the Department. The reasons for this anxiety and the implications of this situation are discussed elsewhere (p. 937), and here it can only be noted that the Advisory Council's report, like the more detailed summary of work, shows clearly how large a contribution the work of the Department continues to make to the national welfare. In visiting the Road Research Laboratory during the year, for example, the Advisory Council was impressed with the way in which work on road safety is taking definite shape, and quantitative results are accruing on which the responsible authorities can base decisions of policy with confidence. The Laboratory's recommendations for successful bituminous surface dressings are now widely known, while during the year reconstruction of a road at Six Hills in Leicestershire has been utilized for full-scale experiments on the prevention of the irregularity in surface finish of concrete roads laid by machinery. Other investigations have been concerned with the present level of the resistance to skidding, when wet, of the roads of three counties and the traffic eapacity of roads, and have revealed the dangers of the present position regarding rear lights.

$A$ visit to the Pest Infestation Laboratory convinced the Advisory Council both of its efficiency and the satisfactory nature of the collaboration with the Infestation Control Division of the Ministry of Agriculture. Largely through this collaboration, the condition of grain in bulk stores at the ports has improved very considerably compared with what it was twelve years ago. This Laboratory, in which a balance has now been struck between research designed to solve practical problems and work of a more fundamental nature, is now devoting more attention to the study of 'domestic' insects, such as flies, carpet beetles and clothes moths. A long-range study of the physical conditions that limit the development of clothes moths, and the application of radioactive tracer techniques to a study of the reaction of fumigants and insects with foodstuffs is already yielding results of immediate practical importance.

The intimate contact and good working conditions of the Food Investigation Organization with the Ministry of Food and, in particular, with the Chief Scientist's Division, have similarly proved invaluable in securing the practical application of scientific results. In this connexion the Advisory Council stresses the importance of the opening of the Ministry's experimental factory at Aberdeen, adjacent to the Torry Research Station, where full-scale processing of foodstuffs will be carried out and it will be possible to study the effects of experimental changes. The Food Investigation Organization will carry out research in connexion with processing at the factory, and a new research vessel, fitted with diesel-electric drive, has been ordered, which will enable the Torry Research Station to work on fish immediately after being caught on the distant fishing grounds, and will also provide fish of known history in sufficient quantities for use in the experimental factory. Other food investigations noted in the report have been concerned with the evaluation and mitigation of certain defects in frozen beef, the curing of ham and bacon, the handling and stowage of fish on board Arctic trawlers, the chemistry of wood smoke and of the constituents of fruits, and the storage of fruit and vegetables; and, besides the further application of ion-exchange chromatography to the analysis of complex mixtures, the more basic research has included the construction of an apparatus for the continuous measurement and the automatic recording of the rate of respiration of vegetable tissues.

The doubling of the expenditure on building research may lend special interest to the account of that work. A formula has been developed which is expected to permit production of a sound cement, meeting the requirements of the British Standard, from the phosphate-bearing limestone found in some of the Colonial territories, and studies in the design of structures have already pointed to substantial savings in the steel used in beems. Work on heating has been dominated for some years by the problem of the small house, and the most important single conclusion reached during the year was that a fair balance of economy and comfort is generally to be found in using a continuous-burning solid fuel fireplace and back-boiler supplying domestic hot-water and two downstairs radiators, together with the use of draught seals on front and rear doors and adequate thermal insulation. The work on building operations and development has continued mainly on the study of productivity and costs of building, the mechanization of building processes and operations and the study of new methods of construction.

Good progress was made during the year in the construction of the permanent building at the Chemical Research Laboratory for radiochemical research. The work of the Laboratory during the year has, however, already been noted in Nature $(169,67 ; 1952)$. An analysis of fires in post-war houses has indicated a significant increase since 1946 in the total annual rate of fires in temporary build ings ; and a special analysis of fires caused by sparks from locomotives indicates that a peak period of fire-incidence tends to follow a fall in relative humidity below 48 per cent, and that this will only be ended by the precipitation of a total rainfall of $6 \mathrm{~mm}$. within three consecutive days. Other fire investigations have been concerned with the initiation and growth of fires, the spread of fire between buildings, the use of water-sprays for fire extinction, and industrial hazards such as the ignition of mixtures of inflammable gases and air by sparks caused by striking rusty iron surfaces coated with aluminium paint.

In the Forest Products Research Laboratory, the main work on wood structure has been directed towards the efficient use of the country's timber supplies and the identification and provision of information on new timbers. The seasoning properties of fifteen species of exotic timber were determined during the year, and studies on the abrasion of timber, "the durability of plywood, the mechanics of veneer peeling, the penetration of wood preservatives and on sawing problems continued. Co-operation in fuel research within the Commonwealth was strengthened during the year by implementation of some of the recommendations of the Commonwealth Conference on Fuel Research of July 1950. Fundamental 
studies on the constitution of coal continued and also on the carbonization, in a setting of intermittent vertical chambers, of Durham coals and of blends of Durham and Northumberland coals to determine the possibility of conserving the limited resources of first-grade coking coals for the production of metallurgical coke. The Fischer-Tropsch process for producing liquid fuels and aliphatic chemicals is being studied with the view of its possible commercial application in Great Britain or elsewhere in the British Commonwealth, while work is also continuing on the elimination of smoke from industrial boilers and on the reduction of external deposits on the heating surfaces of industrial boilers.

The Geological Survey and Museum records only a relatively slow advance towards the completion of a primary six inches to one mile survey of the whole country; but some investigations were made into sources of sulphur in anhydrite and pyrites, and a volume on the "Northampton Sand Ironstone" was issued during the year. A primary well survey of England and Wales, started in 1940, is almost complete. Considerable progress has been made with the development of the new Hydraulics Research Station at Howbery Park, Wallingford. Investigations have continued into the provision of a weir in the River Eden and also the tidal studies in the Wyre estuary at Fleetwood and on the best position for the tide generator in a model of the Thames estuary. The Mechanical Engineering Research Organization expanded steadily during the year, and the building of the Hydraulic Machinery Laboratory was started in July 1951. Most of the work on properties of materials and mechanics of solids continued to be carried out in the National Physical Laboratory. Investigations on the swirling flow of water through a nozzle, with particular reference to boundary conditions, have been resumed at the University of Cambridge, and work on lubrication, wear and corrosion continued at Thorntonhall. The work of the Division of Mechanics of Formation and Machine Shaping of Materials has been divided into four main groups : crystal plasticity; plastic properties of materials; mechanics of formation of materials ; and mechanics of shaping of materials. The buildings and services of the heat transfer laboratory at East Kilbride are now unlikely to be ready before 1954.

At the National Physical Laboratory, the Ship Division has experienced a steady and consistent demand from shipbuilders for routine tests on ship designs of all types, and work has begun on the detection and stimulation of turbulent flow on model propellers. Although the expenditure on radio research has been reduced by more than half and work on the new Radio Research Station at Slough had not commenced, the routine forecasts of ionospheric conditions throughout the world prepared at Slough, based on observations at the ionospheric observing stations maintained by the Department at Fraserburgh (Scotland), Singapore and the Falkland Islands, serve to guide those responsible for the choice of frequencies for communication circuits and other purposes. Much attention has also been paid to the properties of germanium and other semiconductors used in crystal diodes, triodes and photocells. Demands on the Water Pollution Research Organization by government departments, local authorities and industry are heavy and increasing. Investigations on the treatment of sewage by mechanical and biological filtration have absorbed much effort, and experiments are also in progress to develop a method for determining in the laboratory, with a known degree of accuracy, the toxicity to fish of dissolved substances.

The Advisory Council in its report refers particularly to the work and new terms of grant for the next five-year period of seven research associations. For the Printing, Packaging and Allied Trades Research Association, which is now spending about $£ 52,000$ a year, the annual grant will be $£ 12,000$ for the next two years, provided $£ 25,000$ is received from industry, and above that will increase $£ 100$ for $£ 100$ from industry up to a maximum of $£ 10,000$; for 1953-56 it will be $£ 16,000$, conditional on $£ 40,000$ from industry, with an additional $£ 16,000$ on a $£ 100$ for $£ 100$ basis. The Advisory Council is concerned at the slenderness of the industrial contribution and the small scale of operation of the Association, although convinced that the Association's work can be of great value to the printing industry in solving its intricate problems relating to surface action. Its work is already making considerable progress in the reduction of idle time while 'making ready', in colour printing and the electronic evaluation of colour.

For the British Jute Trade Research Association, which now includes 90 per cent of the producing

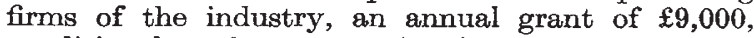
conditional on $£ 15,000$ coming from the industry, is proposed for the next five years; but it is not anticipated that the industry will be able to increase its support much above $£ 17,000$, owing to difficulties arising from the political situation in Pakistan and India. The Association is investigating the numerous fibres, mainly lignified bast fibres in the Hibiscus family, which may be satisfactory alternatives to jute, and as regards jute itself a better understanding of the structure of the fibre in relation to its chemical and physical properties is leading to improvements in finishing treatments.

For the British Scientific Instrument Research Association, which in view of its special importance to defence has always received exceptional treatment and already includes 112 out of the potential 150 members, the existing terms of grant were to be continued to March 1952, and thereafter varied until in 1956 the annual grant would be $£ 30,000$, provided $£ 20,000$ was received from the industry, which, in the Advisory Council's opinion, should considerably increase its support. An additional $£ 20,000$ is also proposed on the basis of a $£ 100$ for every $£ 100$ from the industry.

The Research Association of British Paint, Colour and Varnish Manufacturers has already an industrial income of $£ 30,000$ and includes 90 per cent of the productive side of the industry. The new annual grant will be $£ 15,000$ conditional on the $£ 30,000$ being maintained, with a further $£ 100$ for each $£ 100$ from the industry up to $£ 15,000$. The Association has hitherto concentrated on the study of oils and other materials with the object of conserving scarce materials or finding satisfactory substitutes, but is now turning to the study of the pigmentary qualities of materials not hitherto used.

The British Rayon Research Association, which has earned its maximum grant of $£ 70,000$ since its formation in 1945, contemplates considerable expansion. The fundamental work will be extended to include studies of those properties of man-made fibres which bear on their behaviour in processing and in use, and on the technical side developments which will increase productivity will receive the main 
effort. For the next five years an annual grant of $£ 50,000$ is proposed, conditional on $£ 140,000$ coming from the industry, with up to a further $£ 40,000$ on the usual $£ 100$ for $£ 100$ basis.

Only in the past two years has the British Baking Industries Research Association, formed in 1946, begun to produce research results; but while its work can have little effect on sales, though to some extent it may reduce costs, work like that on the prevention of staling is of great potential value to the general public. The annual grant recommended for the next five years is $£ 11,000$ conditional on $£ 20,000$ coming from the industry, with up to a further $£ 8,000$ on the cent per cent basis. 'The recently formed Cutlery Research Council, covering about 95 per cent of the industry, is a promising attempt to re-establish a co-operative research organization in place of the former Cutlery Research Association, which was dissolved in 1931 owing to lack of support. For this an initial annual grant of $£ 3,000$, conditional on $£ 4,000$ eoming from the industry, is recommended for the next three years, and up to a further $£ 3,000$ on the usual cent per cent basis.

Brief mention can be made here of the work of the remaining research associations. The British Shoe and Allied Trades Research Association has worked on the science of shoe comfort and the appraisement of materials for shoe production; and the British Ceramic Research Association on the properties of raw materials used in the pottery industry and on refractories for the iron, steel and carbonizing industries and its survey of the properties of the important brick-making clays of Great Britain. Besides its work on domestic heating, the British Coal Utilization Research Association has investigated the effects of coal characteristics on boiler performance, and has brought its work on the production of phthalic anhydride and other organic acids by the fluidized flow of catalytic oxidation of phenanthrene to the stage of industrial development. That of the British Electrical and Allied Industries Research Association bears mainly upon the production of electricity, its economical transmission and distribution, its most efficient utilization and the reliability of equipment; but it has also included fundamental work on dielectrics and on the crystal structure of basic magnetic alloy systerns, precipitation alloys and the nature and movement of ferromagnetic domains and their boundaries. The Research Association of British Flour Millers from July I, 1951, has again been given a grant under the Department of Scientific and Industrial Research after eight years under the general supervision of the Minister of Food ; it has continued to test home-grown wheat varieties for milling and baking value, and to work on the structure of wheat endosperm and flow particles. Besides its work on cocoa and chocolate, sugar confectionery, jam, meat, etc., the British Food Manufacturing Industries Research Association has collected and made available much information on food regulations in overseas countries, and has assisted in co-ordinating views on the revision of regulations governing the addition of preservatives and other substances to foods in Great Britain.

The British Hydromechanics Research Association is investigating the reliability of graphical and analogy methods of calculating surge pressures in pipelines and the performance of commercial seals and the fundamental processes involved. The British Iron and Steel Research Association has established the feasibility of treating powdered ore to render it suitable for use in blast furnaces, and a co-operative study indicated the possibility of appreciable economy of fuel and increased output by automatic rooftemperature control in open-hearth furnaces. The Design and Research Centre for the Gold, Silver and Jewellery Industries has developed a new process for giving an attractive lustrous glitter to fancy jewellery and articles by vacuum evaporation of metals such as aluminium, while the British Launderers' Research Association has directed attention to the serious damage to textile fabrics caused by the unskilful use by the general public of proprietary brands of bleach for the removal of stains - damage frequently wrongly attributed to the use of bleach or rough handling in the laundry. During the second quarter of 1951, fortyfour firms tested 847 vehicles on the proving ground of the Motor Industry Research Association near Nuneaton. The British Paper and Board Industry Research Association has developed a new pulping process which operates at atmospheric pressure; by this method, whole wheat straw in bales can be utilized either for semi-pulp or for the production of writing paper. An important contribution from the Research Association of British Rubber Manufacturers is on the mechanism of the rapid deterioration of popular single-texture mackintoshes induced by minute traces of copper compounds, and means of preventing it are now being studied.

These examples should sufficiently indicate how varied and important is the contribution which the work of the research associations and indeed of the Department of Scientific and Industrial Research as a whole is making both to industrial efficiency and productivity and to almost every side of national welfare and daily life.

\section{FORTY YEARS OF X-RAY DIFFRACTION}

\section{By Prof. J. M. BijVoet (President), Prof. J. D. BERNAL, F.R.S., and Prof. A. L. PATTERSON International Union of Crystallography}

GORTY years ago, on June 8, 1912, the first 1 account of diffraction experiments of X-rays by crystals, by Friedrich, Knipping and von Laue, was published in the Sitzungsberichte der Bayerischen Akademie der Wissenschaften. This event, among the most important discoveries of twentieth-century science, is being commemorated this year by the International Union of Crystallography; and the X-Ray Analysis Group of the Institute of Physics, at the instance of the British National Committee for Crystallography, is arranging a special meeting to be held at the Royal Institution during October 24-25, at which it is hoped that Prof. M. von Laue and Sir Lawrence Bragg will speak.

The experimental verification of von Laue's ingenious idea of three-dimensional diffraction substantiated at the same time the wave character of $\mathrm{X}$-rays, then in dispute, and the reality of the abstract and mathematical lattice theory of crystals. The result was to open two new fields of science, namely, that of X-ray spectroscopy, which with Moseley's work was to provide decisive support to the quantum theory of the atom, and that of erystal structure determination, destined to have an even greater importance to chemistry. 